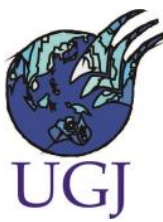

\title{
Meningkatkan Hasil Belajar Geografi Dengan Menggunakan Media Pembelajaran Powerpoint Pada Materi Dinamika Litosfer di Kelas X IPS 2 SMA Negeri 1 Baubau
}

\author{
Irwan $^{1}$, La Harudu ${ }^{2}$ \\ ${ }^{12}$ Universitas HaluOleo Fakultas Keguruan dan Ilmu Pendidikan \\ Program Studi Pendidikan Geografi \\ Email : irwanfkipgeografi@gmail.com
}

(Received: Maret 2019; Reviewed: Maret 2019; Accepted: April 2019; Published: 01 Mei 2019)

Ini adalah artikel dengan akses terbuka dibawah license CC BY-NC-4.0 (C2019 oleh penulis (https://creativecommons.org/licenses/by-nc/4.0/ ).

\begin{abstract}
SMAN 1 Baubau is one of the schools in Baubau City, Bataraguru Village, which is the object of research by researchers because its learning outcomes are still low, this is because only $38 \%$ of them meet the KKM. The objectives of the study were: (1) to find out the learning activities of students of class X IPS2 and teaching activities of teachers of SMAN 1 Baubau when applying powerpoint media, (2) to find out the geography learning outcomes of IPS X class 2 students of Baubau Public High School taught with powerpoint based learning media this is done in class X IPS2 of SMAN 1 Baubau even semester of school year 2018/2019, dated January 72019 to February 6, 2019. This type of research is classroom action research $(P T K)$ which is conducted in two cycles. The subjects of this research are teachers and class students X IPS2 SMAN 1 Baubau. The data in the study are qualitative and quantitative data obtained from observation sheets and learning outcomes tests. From the analysis results, it can be concluded that by applying powerpoint media (1). Student learning activities increase with an average score of 3.1 categorized well. (2). Teacher teaching activities increased with an average score of 3.3 categorized well. (3). Geographical learning outcomes of students of class X IPS2 at SMAN 1 Baubau increased with an average score of 81, with $80 \%$ learning completeness or 35 students with a value of $\geq 72$ according to KKM geography.
\end{abstract}

Keywords: Powerpoint learning media; learning outcomes; Geography; Baubau

\begin{abstract}
ABSTRAK
SMAN 1 Baubau adalah salah satu sekolah di Kota Baubau Kelurahan Bataraguru yang menjadi objek penelitian peneliti karena hasil belajarnya yang masih rendah, hal ini disebabkan hanya 38\% yang memenuhi KKM. Tujuan penelitian: (1)untuk mengetahui aktivitas belajar siswa kelas X IPS2 dan aktivitas mengajar guru SMAN 1 Baubau saat menerapkan media powerpoint,(2) untuk mengetahui hasil belajar geografi siswa kelas X IPS2 SMAN 1 Baunau yang diajarkan dengan media pembelajaran bebasis powerpoint.Penelitian ini dilakukan dikelas X IPS2 SMAN 14 Bombana semester genap tahun ajaran 2018/2019, tanggal 07 januari 2019 sampai dengan tanggal 6 februari 2019. Jenis peneliitian adalah penelitian
\end{abstract}


tindakan kelas (PTK) yang dilaksanakan dengan dua siklus.Subjek penelitian ini adalah guru dan siswa kelas X IPS2 SMAN 1 Baubau. Data dalam penelitian adalah data kualitatif dan kuantitatif yang diperoleh dari lembar observasi dan tes hasil belajar. Dari hasil analisis diperoleh kesimpulan bahwa dengan menerapkan media powerpoint (1). Aktivitas belajar siswa meningkat dengan skor rata-rata 3,1 berkategorikan baik.(2). Aktivitas mengajar guru meningkat dengan skor rata-rata 3,3 berkategorikan baik.(3). Hasil belajar geografi siswa kelas X IPS2 SMAN 1 Baubau meningkat dengan skor rata-rata 81, dengan ketuntasan belajar 80\% atau terdapat 35 siswa dengan nilai $\geq 72$ sesuai KKM geografi.

Kata Kunci: Media pembelajaran powerpoint; hasil belajar; Geografi; Baubau

\section{PENDAHULUAN}

Pendidikan merupakan bagian terpenting dalam pembangunan negara. Berdasarkan Undang-Undang Sisdiknas No. 20 Tahun 2003 Pendidikan adalah usaha sadar dan terencana untuk mewujudkan suasana belajar dan proses pembelajaran agar peserta didik secara aktif mengembangkan potensi dirinya untuk memiliki kekuatan spiritual keagamaan, pengendalian diri, kepribadian, kecerdasan, akhlak mulia, serta keterampilan yang diperlukan dirinya, masyarakat, bangsa dan negara.

Semakin majunya perkembangan ilmu pengetahuan dan teknologi membawa implikasi meluasnya cakrawala manusia dalam berbagai bidang pengetahuan lebih khusus pada bidang pendidikan.

Menurut Sa'ud (2007) Pendidikan merupakan upaya yang dapat mempercepat perkembangan potensi manusia unntuk mampu mengembang tugas yang diberikan padanya . Pendidikan dapat mempengaruhi pendidikan fisik, mental, emosional, moral serta keimanan dan ketakwaan manusia sendiri.

Dari pendapat tersebut di atas dapat disimpulkan bahwa belajar adalah berubahnya tingkah laku seseorang sebagai akibat dari stimulus lingkungan. Sementara pembelajaran adalah rangkaian kegiatan untuk membantu proses belajar seseorang yang melibatkan seorang guru atau pembimbing.

Dalam menjalankan tugasnya, guru juga harus menggunakan alat bantu yang bisa digunakan untuk mempermudah penyampaian materi yang akan diajarkan, seperti media pembelajaran. Salah satu factor rendahnya mutu pendidikan adalah disebabkan oleh proses pembelajaran yang masih sederhana dengan menggunakan media yang tidak variatif. Selain itu, belum diterapkan media pembelajaran yang dapat meningkatkan penyerapan informasi dalam ingatan diperlukan media yang tepat ( zakiuddin, $2005: 45$ )

Berdasarkan hasil observasi dan wawancara dengan guru geografi dan beberapa siswa SMA Negeri 1 Baubau bahwa sebagian besar hasil belajar dikelas tersebut masih rendah. Hal ini di tandai dengan rendahnya rata-rata nilai ulangan harian pada bab-bab sebelumnya pada tahun ajaran 2017/2018. Dari ulangan harian pada kelas X IPS2 SMA Negeri 1 Baubau yang terdiri dari 26 orang siswa, orang siswa yang memperoleh nilai $\geq 70$ hanya 16 orang siswa yang tuntas atau $61,54 \%$ sedangkan yang memperoleh nilai $<72$ sebanyak 10 orang siswa yang tidak tuntas atau sekitar $38,46 \%$ nilai tersebut masih tergolong rendah dari nilai KKM untuk mata pelajaran geografi yaitu 72 .

Perubahan perilaku berbicara, menulis, bergerak dan lainnya, memberi kesempatan kepada manusia untuk mempelajari perilakuperilaku seperti berpikir, merasa, mengingat, memecahkan masalah, berbuat kreatif, perubahan ini termasuk hasil belajar (Endang Komara, 2014: 11)

Dari pendapat tersebut dapat disimpulkan bahwa hasil belajar merupakan suatu puncak proses belajar. Hasil belajar tersebut terjadi terutama berkat evaluasi guru. Hasil belajar dapat berupa dampak pengajaran dan dampak pengiring. Kedua dampak tersebut bermanfaat bagi guru dan siswa. 
Berdasarkan hasil observasi awal tersebut diperlukan perbaikan yang dapat mendorong siswa untuk aktif dalam mengikuti proses pembelajaran Geografi. Adapun upaya yang dapat dilakukan untuk meningkatkan kualitas proses dan hasil pembelajaran geografi adalah dengan membuat variasi media pembelajaran salah satunya yaitu menerapkan penggunaan media Powerpoint.

Media Powerpoint adalah suatu software (program) yang akan membantu dalam menyusun sebuah presentasi yang efektif, profisional dan juga mudah. Menurut Riyana (208) bahwa program Microsoft Office Powerpoint adalah salah satu software yang dirancang khusus untuk mampu menampilkan program multimedia dengan menarik, mudah dalam pembuatan, mudah dalam penggunaan dan relative murah karena tidak membutuhkan bahan baku selain alat untuk menyimpan data (data storage)..

Menurut Sriyanto (2009) Powerpoint merupakan program Microsoft Office yang dirancang khusus untuk menyampaikan presentase, baik yang diselenggarakan oleh perusahaan, pemerintah, maupun perorangan dengan berbagai fitur menu yang menjadikannya sebagai media komunikasi yang menarik. Powerpoint digunakan karena kemampuannya dalam mengelola teks, warna, gambr, grafik serta animasi-animasi yang bisa diolah sendiri sesuai kreatifitas penggunannya.

Menurut Sriyanto (2009) bahwa penggunaan powerpoint memiliki kelebihan yaitu 1) Penyajiaanya yang menarik karena ada permainan warna, huruf dan animasi, baik animasi teks maupun animasi gambar dan foto. 2) Lebih merangsang anak untuk mengetahui lebih jauh informasi tentang bahan ajar yang tersaji. 3) Pesan informasi secara visual mudah dipahami peserta didik. 4) Tenaga pendidik tidak perlu banyak menerangkan bahan ajar yang sedang disajikan..

Terdapat beberapa langkah yang perlu diketahui dalam memanfaatkan media Powerpoint untuk kegiatan pembelajaran. Langkah-langkah tersebut meliputi langkah persiapan, langkah pelaksanaan, dan langkah tindak lanjut (Daryanto, 2010: 46).

\section{METODE}

\section{Jenis Penelitian,}

Jenis penelitian adalah Penelitian Tindakan Kelas (PTK) adalah penelitian praktis untuk memperbaiki pembelajaran di kelas, Penelitian tindakan kelas merupakan suatu bentuk penelitian reflektif dan kolektif yang di lakukan peneliti dalam situasi sosial dalam meningkatkan penalaran praktik sosial mereka.

\section{Tempat dan Waktu Penelitian,}

Penelitian ini dilakukan di SMA Negeri Baubau yang beralamat di Bataraguru, Wolio, Kota Baubau, Provinsi Sulawesi Tenggara. Penelitian ini dilakukan selama satu bulan, yakni mulai bulan januari sampai akhir bulan januari 2019.

\section{Subjek Penelitian}

Subjek penelitian ini adalah guru dan siswa kelas $X$ IPS IPS2 SMA Negeri 1 Baubau. Jumlah siswa sebanyak 35 orang yang terdiri dari 13 orang laki-laki dan 22 orang perempuan.

\section{Teknik Analisis Data}

Data yang diperoleh dalam penelitian ini, dianalisis menggunakan analisis statistik deskriptif yang meliputi: rata-rata hasil belajar, persentase hasil ketuntasan belajar siswa, rata-rata aktivitas siswa dan rata-rata aktivitas guru.

Nilai rata-rata hasil belajar

$$
\mathrm{Xi}=\text { spi/smx } 100 \%
$$

(Usman dan Setiawati, 2001).

\section{Keterangan:}

$\mathrm{Xi}=$ nilai yang diperoleh siswa ke- $\mathrm{i}$

Spi = skor yang diperoleh siswa ke-i

$\mathrm{Sm}=$ skor maksimal menentukan

Nilai rata-rata hasil belajar siswa=

$$
\begin{aligned}
& \text { skor data yang diperoleh seluruh siswa } \\
& \text { jumlah siswa } \\
& \text { (suparno,2008:81) }
\end{aligned}
$$

Presentase Keberhasilan aktivitas belajar siswa dengan rumus:

$$
\% \text { Tuntas }=\left(\sum \mathrm{TB}\right) / \mathrm{NX} 100 \%
$$


Keterangan

$\sum$ TB $=$ jumlah siswa yang tuntas belajar (sudjana,2002)

$\mathrm{N}=$ jumlah siswa secara keseluruhan

d. mengklarifikasi rata-rata skor aktivitas siswa

$1 \leq \mathrm{Xi}<2$ : kategori kurang

$2 \leq \mathrm{Xi}<3$ : kategori cukup

$3 \leq \mathrm{Xi}<4$ : kategori baik

$\mathrm{Xi}=4$ : kategori sangat baik

(Susetyo, 2010)

\section{HASIL DAN PEMBAHASAN}

\section{Pelaksanaan Tindakan siklus I \\ Perencanaan}

Hal-hal yang dilakukan pada tahap perencanaan ini adalah: 1) menyiapkan RPP sesuai dengan Langkah-langkah media powerpoint untuk pertemuan I dan peretmuan II, 2) menyiapkan lembar kerja siswa (LKS 01 dan LKS 02), 3) mempersiapkan sumber, bahan, dan alat bantu yang dibutuhkan, 4) menyiapkan lembar observasi pebelajaran (format observasi siswa dan guru), 5) menyusun soal evaluasi tes hasil belajar siswa berupa essay.

\section{Pelaksanaan Tindakan}

Pelaksanaan tindakan pada siklus I dilaksanakan dalam dua kali pertemuan sesuai dengan RPP.

\section{Aktivitas siswa pertemuan I dan II siklus I}

Gambaran rata-rata aktivitas siswa dengan menerapkan model pembelajaran berbasis masalah pada siklus I untuk setiap aspek aktivitas yang dinilai dapat dilihat pada Gambar 3.1 berikut:

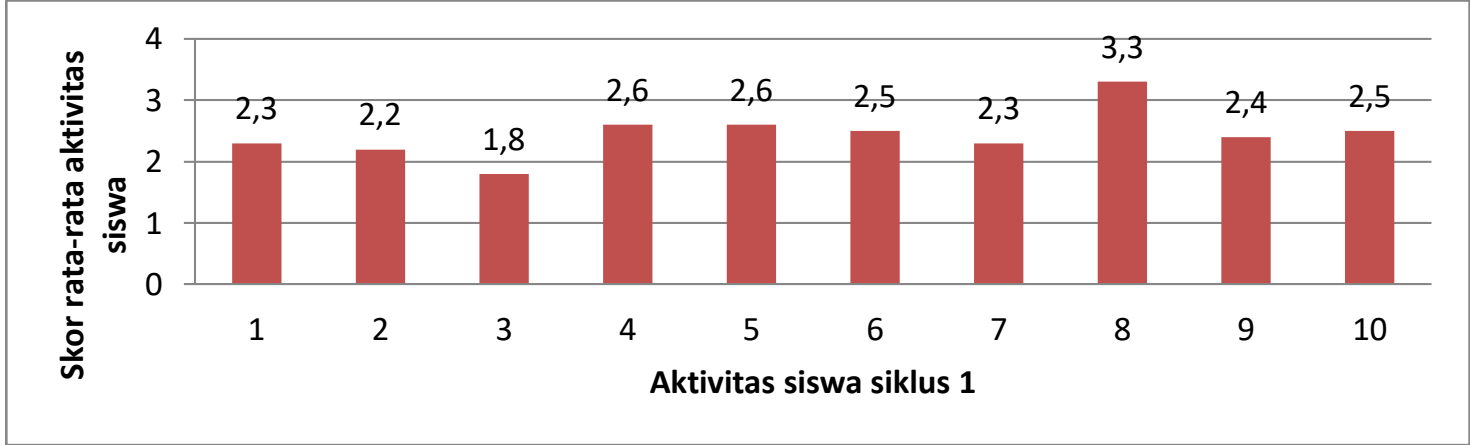

Gambar 1.Grafik Skor Rata-Rata Aktivitas Siswa Pada Siklus I(Analisis Data Primer, 2019)

Keterangan:

1. Siswa mendengar dan memperhatikan guru menyampaikan tujuan pembelajaran melalui slide

2. Siswa mendengarkan dan memperhatikan penjelasan guru mengenai materi pembelajaan melaui Powerpoint

3. Menjawab pertanyaan yang yang diberikan oleh guru dengan benar.

4. Mencari kelompok masing-masing yang telah dibagi oleh guru.

5. Siswa berdiskusi dengan kelompoknya dalam memecahkan masalah.

6. Bekerja sama dalam menyelesaikan masalah yang ada pada LKS.

7. Bekerja sama dalam menyiapkan laporan hasil diskusi kelompok.

8. Masing-masing kelompok mempresentasikan hasil diskusi di depan kelas.
9. Menyimak \& menanggapi hasil diskusi kelompok lain

10. Menyimak penguatan dan koreksi dari guru tentang hasil diskusi kelompok.

Berdasarkan gambar di atas tentang hasil observasi aktivitas siswa dapat diperoleh gambaran bahwa, hasil aktivitas siswa tersebut masih belum memenuhi kriteria ketuntasan minimal yaitu 3,0 karena rata-rata aktivitas siswa masih mencapai rata-rata 2,5 yang berkategorikan cukup. Dimana pada siklus I aktivitas siswa yang mendapatkan skor terendah dengan nilai rata-rata sebesar 1,85 adalah aktivitas nomor 3 yaitu Menjawab pertanyaan yang diberikan oleh guru dengan benar. Sedangkan aktivitas siswa yang mendapat skor tertinggi adalah aktivitas nomor 8 yaitu Masing-masing kelompok mempresentasikan hasil diskusi di depan kelas dengan nilai 3,4 . 
Rata-rata aktivitas siswa selama dapat dilihat pada Gambar 3.2 berikut: pembelajaran pada siklus I pertemuan I dan II

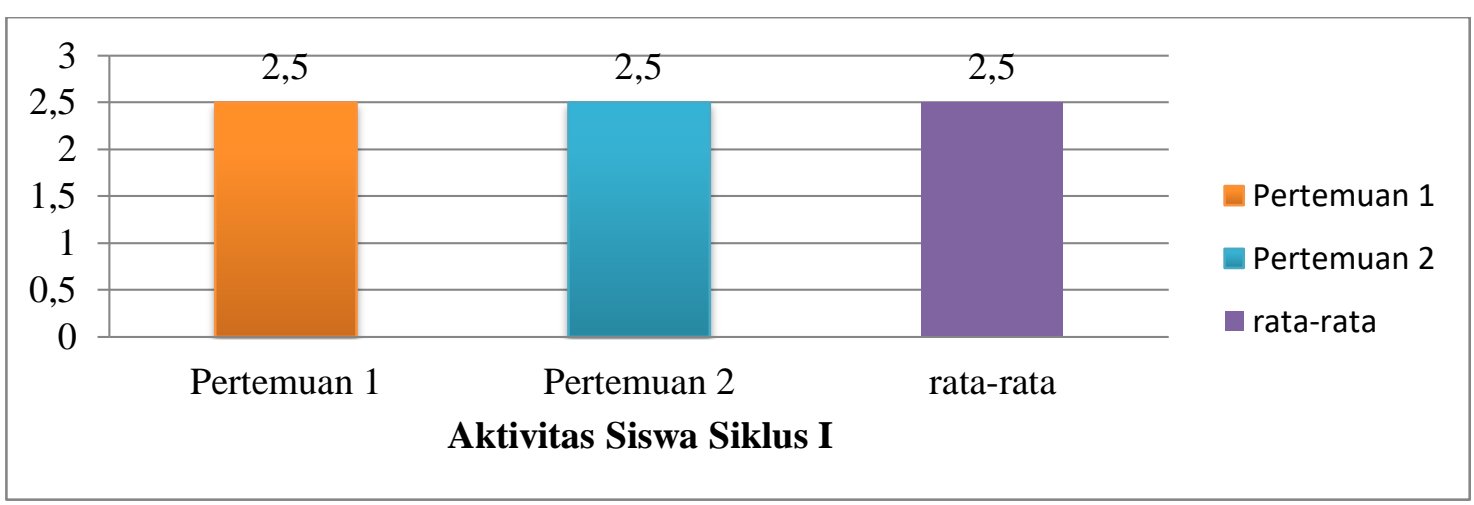

Gambar 2. Grafik Skor Rata-Rata Aktivitas Siswa Siklus I Pertemuan 1 Dan 2 (Analisis Data Primer, 2019)

Berdasarkan gambar 3.2 di atas, dapat dikatakan bahwa aktivitas siswa di siklus I masih tergolong cukup hal itu dikarenakan belum mencapai batas ketuntasan yang di tetapkan yaitu $\geq 3,0$.

\section{Aktivitas mengajar guru pertemuan I dan II siklus I}

Gambaran rata-rata aktivitas mengajar guru dalam proses pembelajaran dengan menggunakan model pembelajaran berbasis masalah pada materi pelestarian lingkungan hidup yang diperoleh dengan menggunakan lembar observasi aktivitas guru pada siklus I dapat dilihat pada gmbar 3.3 berikut:

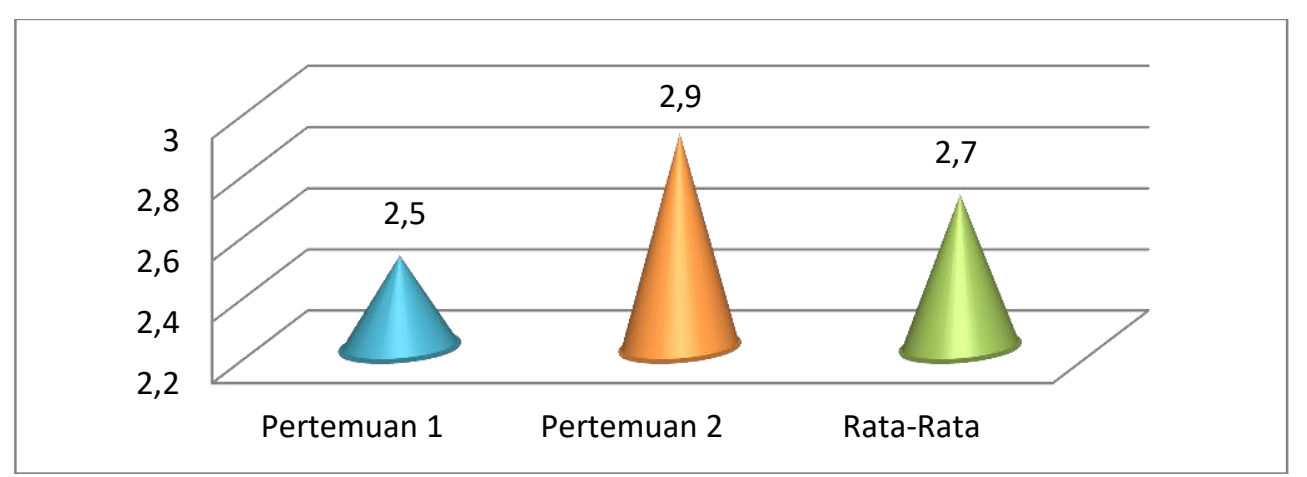

Gambar 3.Grafik Skor Rata-Rata Aktivitas Guru SiklusI (Analisis Data Primer, 2019)

Berdasarkan gambar 3 di atas menunjukkan bahwa, aktivits guru masih belum memenuhi kriteria ketuntasan minimal yaitu 3,0 karena aktivitas guru masih mencapai rata-rata 2,7 yang berkategorikan cukup.

\section{Hasil belajar siswa pertemuan I dan II siklus I}

Untuk hasil belajar siswa pada siklus I diperoleh melalui tes yang diberikan di akhir pertemuan siklus dan dapat dilihat melalui tabel berikut:

Tabel 1.Data anlisis ketuntasan hasil belajar siswa pada siklus I

\begin{tabular}{cccc}
\hline Skor & Jumlah siswa & Persentase & Ketuntasan belajar \\
& & & Tidak Tuntas \\
$0-71$ & 16 & $46 \%$ & Sudah Tuntas \\
$72-100$ & 19 & $54 \%$ & \\
Jumlah & 35 & $100 \%$ &
\end{tabular}


Tuntas

Tidak Tuntas

Nilai rata-rata

Nilai maksimum

Nilai minimum

Persentase ketuntasan

\section{Keterangan}

19 orang

16 orang

69

93

53

$54 \%$

\section{Sumber: Analisis Data Primer, 2019.}

Data di atas menunjukan bahwa hasil belajar siswa pada siklus I yang memperoleh skor antara 0-71 berjumlah 16 orang dengan persentase $46 \%$ sedangkan siswa yang memperoleh skor 72-100 berjumlah 19 orang dengan persentase mencapai 54\% namun itu belum mencapai indikator ketuntasan keberhasilan yaitu $80 \%$ siswa yang mencapai ketuntasan hasil belajar. Untuk lebih jelasnya gambaran hasil belajar yang sudah tuntas dan yang belum tuntas siklus I dapat dilihat pada gambar 3.4 berikut

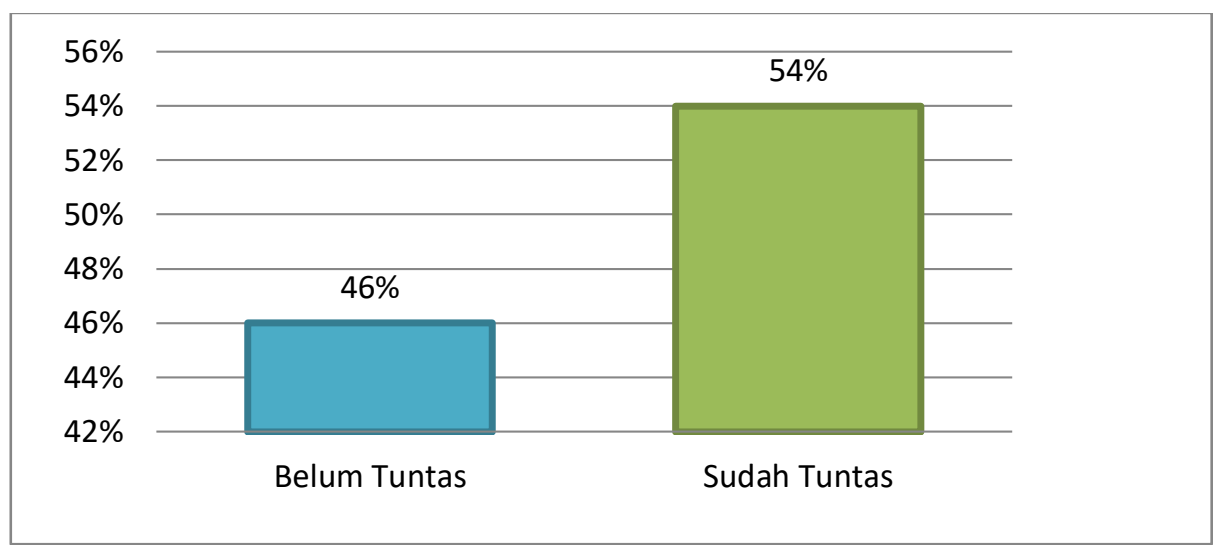

Gambar 4.Presentase Ketuntasan Hasil Belajar Siswa Siklus I (Analisis Data Primer, 2019)

Oleh karena di siklus I hipotesis tindakan penelitian belum tercapai maka perlu dilanjutkan kesiklus II dengan tujuan mencari jawaban atas hipotesis.

\section{Pelaksanaa tindakan siklus II}

\section{Perencanaan}

Setelah mengetahui kekurangan yang terjadi pada siklus I baik yang dilakukan oleh siswa maupun guru, maka pada pembelajaran siklus II guru mencoba memperbaiki kesalahan yang dilakukan sebelumnya, sehingga hasil belajar dengan menerapkan model problem based learning dapat tercapai sesuai indikator keberhasilan yaitu $80 \%$.

\section{Pelaksanaan tindakan}

Pelaksanan tindakan pada siklus II dilaksanakan dalam dua kali pertemuan sesuai RPP.

\section{Aktivitas belajar siswa pertemuan I dan II siklus II}

Gambaran rata-rata aktivitas siswa dengan menerapkan model pembelajaran berbasis masalah pada siklus II untuk setiap aspek aktivitas yang dinilai dalam dua pertemuan dapat dilihat pada Gambar 3.5 berikut: 


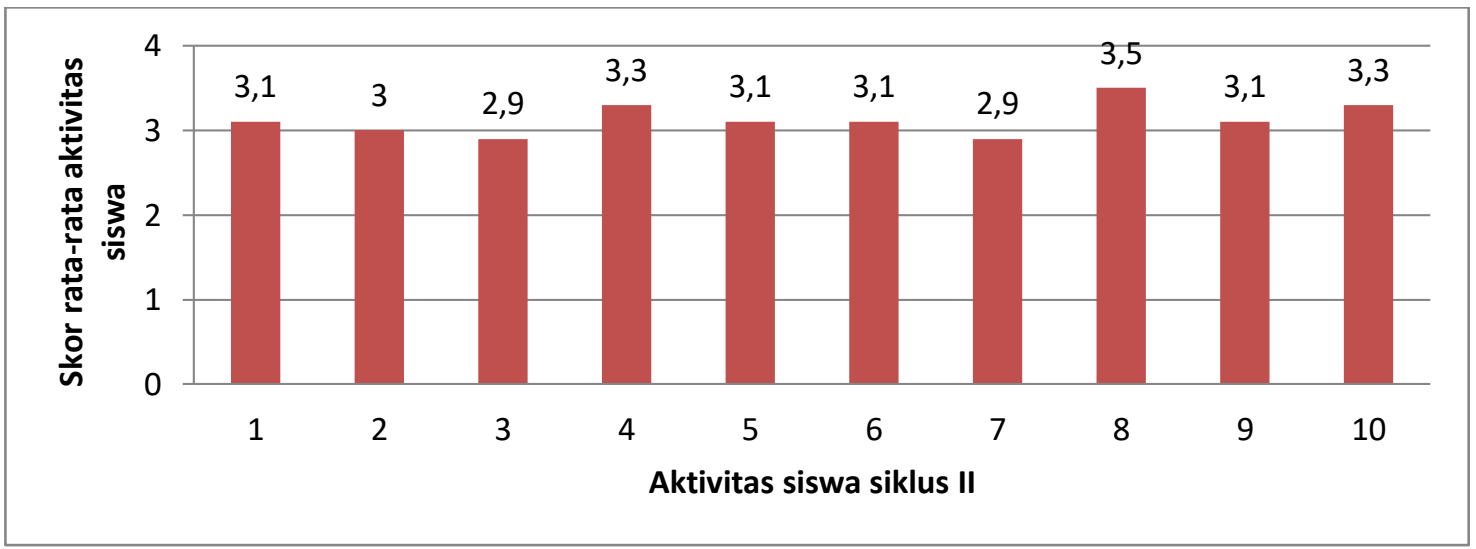

Gambar 5.Grafik Skor Rata-Rata Aktivitas Siswa Pada Siklus II(Analisis Data Primer, 2019)

Keterangan:

1. Siswa mendengar dan memperhatikan guru menyampaikan tujuan pembelajaran melalui slide

2. Siswa mendengarkan dan memperhatikan penjelasan guru mengenai materi pembelajaan melaui Powerpoint

3. Menjawab pertanyaan yang yang diberikan oleh guru dengan benar.

4. Mencari kelompok masing-masing yang telah dibagi oleh guru.

5. Siswa berdiskusi dengan kelompoknya dalam memecahkan masalah.
6. Bekerja sama dalam menyelesaikan masalah yang ada pada LKS.

7. Bekerja sama dalam menyiapkan laporan hasil diskusi kelompok.

8. Masing-masing kelompok mempresentasikan hasil diskusi di depan kelas.

9. Menyimak \& menanggapi hasil diskusi kelompok lain

10. Menyimak penguatan dan koreksi dari guru tentang hasil diskusi kelompok.

Untuk mendapatkan gambaran rata-rata aktivitas siswa siklus II selama pembelajaran dapat dilihat pada gambar 3.6 berikut:

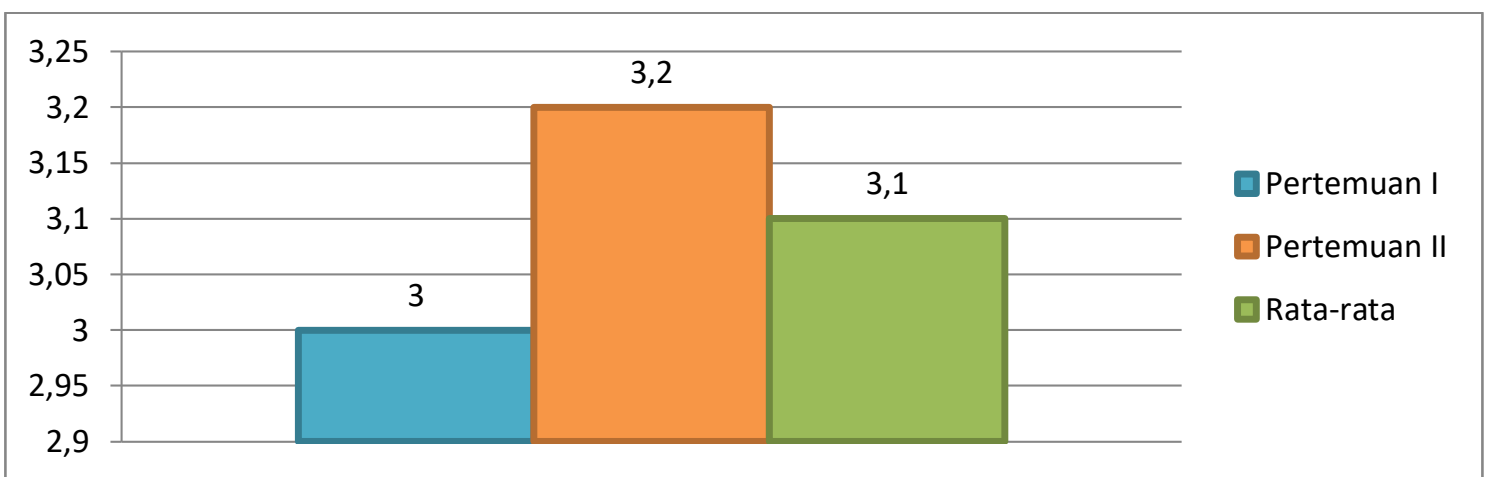

Gambar 6.Grafik Skor Rata-Rata Aktifitas Siswa Siklus II Pertemuan 1 Dan 2(Analisis Data

Primer, 2019)

Berdasarkan gambar 3.6 di atas menunjukan bahwa, aktivitas siswa telah memenuhi kriteria ketuntasan minimal yaitu 3,0. Dimana aktivitas siswa telah mencapai rata-rata 3,1 yang berkategorikan baik.

\section{Aktivitas mengajar guru pertemuan I dan II siklus II}

Gambaran rata-rata aktivitas mengajar guru dalam proses pembelajaran dengan menggunakan model pembelajaran berbasis masalah pada materi pelestarian lingkungan hidup yang diperoleh dengan menggunakan 
lembar observasi aktivitas guru pada siklus I dapat dilihat pada gmbar 3.7 berikut:

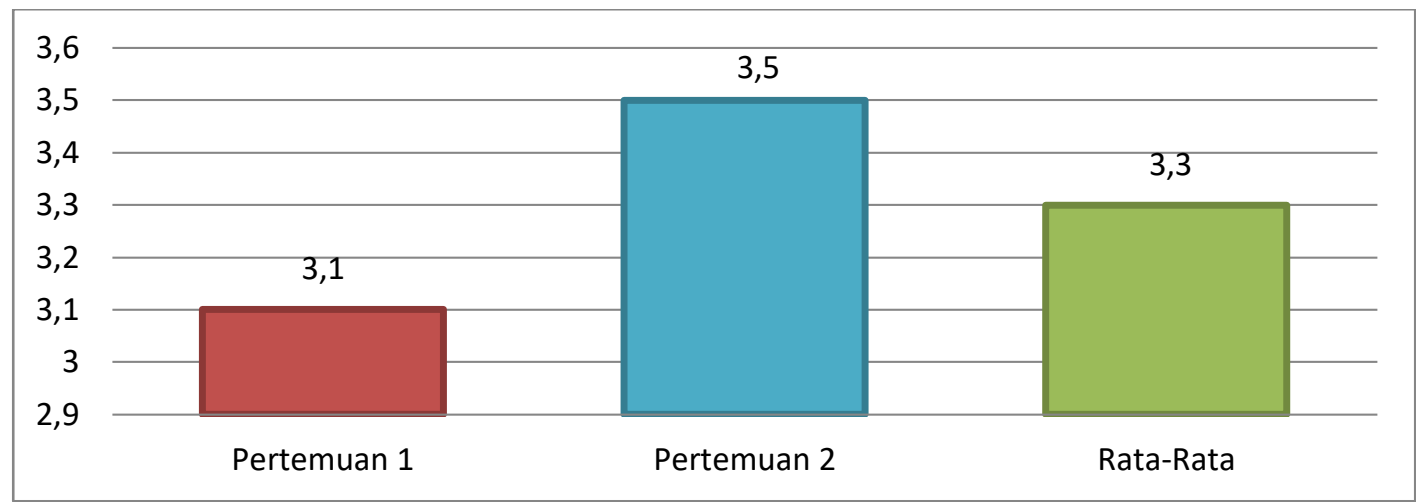

Gambar 7. Grafik Skor Rata-Rata Aktivitas Guru Pada Siklus I (Analisis Data Primer, 2019)

Berdasarkan gambar 3.7 di atas menunjukkan bahwa, aktivitas guru telah memenuhi kriteria ketuntasan minimal yaitu 3,0 karena aktivitas gruru telah mencapai rata-rata 3,3 yang berkategorikan baik.

\section{Hasil belajar siswa pertemuan I dan II siklus II}

Untuk hasil belajar siswa pada siklus II diperoleh melalui tes yang diberikan di akhir pertemuan siklus dan dapat dilihat melalui tabel berikut:

Tabel 2.Data Anlisis Ketuntasan Hasil Belajar Siswa Pada Siklus II

\begin{tabular}{cccc}
\hline Skor & Jumlah siswa & Persentase & $\begin{array}{c}\text { Ketuntasan } \\
\text { belajar }\end{array}$ \\
\hline $0-71$ & 7 & $20 \%$ & Belum Tuntas \\
$70-100$ & 28 & $80 \%$ & Sudah Tuntas \\
Jumlah & 35 & $100 \%$ & \\
& Keterangan & \multicolumn{2}{c}{28 orang } \\
Tuntas & & \multicolumn{2}{c}{7 orang } \\
Tidak Tuntas & & \multicolumn{2}{c}{81} \\
Nilai rata-rata & & \multicolumn{2}{c}{93} \\
Nilai maksimum & & \multicolumn{2}{c}{60} \\
Nilai minimum & & \multicolumn{2}{c}{$80 \%$} \\
Persentase ketuntasan & & &
\end{tabular}

Sumber: Analisis Data Primer, 2019

Untuk mendapatkan gambaran hasil belajar siswa yang sudah tuntas dan yang belum tuntas pada siklus II dapat dilihat pada gambar 3.8 berikut

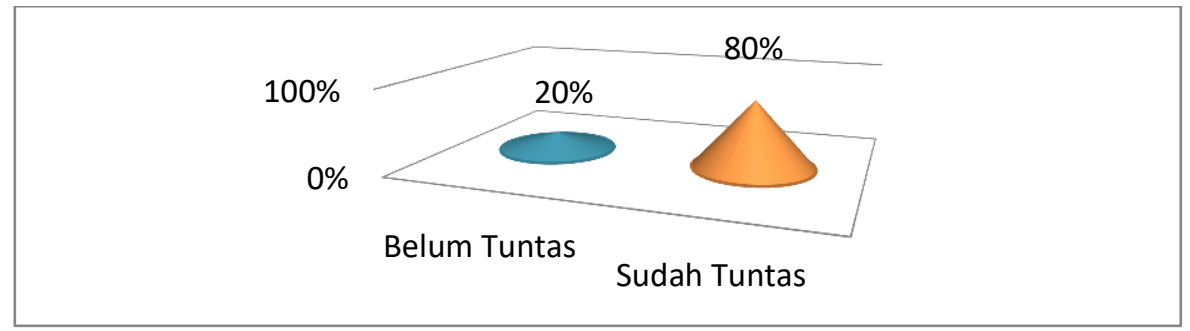

Dari tabel 3.2 dan gambar 3.8 di atas menunjukan bahwa ketuntasan belajar siswa pada siklus II yang memperoleh skor antara 0-71 berjumlah 7 dari 35 siswa dengan persentase $20 \%$. Sedangkan siswa yang memperoleh skor antara 72-100 berjumlah 28 dari 35 siswa dengan 
persentase ketuntasan $80 \%$. Hasil ini sudah lebih baik jika dibandingkan dengan skor perolehan siswa siklus I. Dengan demikian indikator ketuntasan belajar siswa telah tercapai dan itu artinya penelitian ini berhasil karena secara klasikal kriteria ketuntasan yang di tetapkan sebagai indikator berhasilnya pembelajaran yaitu $80 \%$ sudah terpennuhi.

\section{PEMBAHASAN}

\section{Aktivitas belajar siswa pembelajaran berlangsung}

Berdasarkan hasil pengamatan pada dua siklus baik itu siklus I maupun siklus II aktivitas belajar siswa menunjukan peningkatan ke arah yang lebih baik. Hal itu tentu dipengaruhi oleh semangat yang besar oleh siswa dalam mencapai hasil yang optimal.

Pada siklus I berdasarkan hasil analisis deskriptif terhadap aktivitas siswa menunjukan skor rata-rata sebesar 2,5 yang berkategori cukup. Hal tersebut dikarenakan masih ada beberapa aktivitas siswa yang tergolong kurang optimal. Berdasarkan hasil refleksi siklus I ditemukan ada beberapa aktivitas siswa yang belum terlaksana dengan baik salah satunya siswa kurang menjawab pertanyaan yang diberikan oleh guru dengan benar, kurang bekerja sama dalam menyelesaikan tugas kelompok. Oleh karena masih belum optimalnya aktivitas belajar siswa maka diperlukan perbaikan pada siklus selanjutnya. Pada siklus II dari hasil analisis deskriptif terhadap skor rata-rata aktivitas siswa mengalami peningkatan yang sangat signifikan dari aktivitas siswa siklus I. Dimana skor rata-rata aktivitas siswa pada siklus II sebesar 3,1 yang berkategorikan baik.

\section{Aktivitas mengajar guru selama pembelajaran berlangsung}

Berdasarkan hasil pengamatan pada dua siklus baik itu siklus I maupun siklus II, untuk aktivitas mengajar guru menunjukan peningkatan ke arah yang lebih baik. Hal itu tentu dipengaruhi oleh semangat yang besar oleh guru dalam mencapai hasil yang optimal.

Pada siklus I berdasarkan analisis deskiptif aktivitas mengajar guru menunjukan skor ratarata sebesar 2,7 yang berkategorikan cukup. Hal itu tentu dipengaruhi oleh adanya beberapa aktivitas yang belum terlaksana secara optimal. Hasil refleksi aktivitas mengajar guru pada siklus 1 yang masih rendah diantaranya adalah:Guru melakukan apersepsi tentang materi yang akan dipelajari, Guru mengarahkan kepada tiap-tiap kelompok untuk melakukan kegiatan sesuai dengan petunjuk dalam LKS, Guru mengevaluasi terhadap hasil diskusi siswa.

Berdasarkan hasil refleksi tersebut maka diperlukan pembenahan, agar diperoleh peningktan aktivitas mengajar guru sesuai dengan kriteria ketuntasan yang telah ditetapkan. Pembenahan tersebut dilakukan pada siklus II, pada siklus II berdasarkan hasil analisis deskriptif menjelaskan bahwa aktivitas mengajar guru mengalami peningkatan yang signifikan dengan skor rata-rata sebesar 3,3 yang berkategori baik.

Dengan demikian, dapat disimpulkan bahwa aktivitas belajar siswa dan aktivitas mengajar guru selama proses pembelajaran dari siklus I sampai siklus II mengalami peningkatan. Dengan data ini pula dapat disebutkan bahwa dengan menerapkan Media Pembelajaran Powerpoint dapat meningkatkan aktivitas belajar siswa dan aktivitas mengajar guru selama proses pembelajaran geografi pada siswa kelas X IPS SMA Negeri 1 Baubau.

\section{Hasil belajar siswa}

Hasil belajar siswa pada siklus I yang memperoleh skor antara 0-71 berjumlah 16 orang dengan persentase $46 \%$ sedangkan siswa yang memperoleh skor $72-100$ berjumlah 19 orang dengan persentase mencapai $64 \%$ namun itu belum mencapai indikator ketuntasan keberhasilan yaitu $80 \%$ siswa yang mencapai ketuntasan hasil belajar. Rendahnya hasil belajar siswa ini di sebakan karena Siswa belum terbiasa dengan media pembelajaran berbasis masalah terkhusus pada kegiatan diskusi. Siswa masih malu mengungkapkan pendapatnya dalam proses pembelajaran yang sedang berlangsung. Selain aktivitas siswa terdapat aktivitas guru yang masih kurang optimal seperti kurang memberikan kesempatan kepada siswa untuk bertanya terkait materi yang di pelajarai saat proses pembelajaran berlangsung, Guru belum maksimal memberikan kesimpulan secara singkat tentang materi yang telah di presentasikan siswa. 
Tabel 3.Data Anlisis Ketuntasan Hasil Belajar Siswa Pada Siklus I

\begin{tabular}{cccc}
\hline Skor & Jumlah siswa & Persentase & Ketuntasan belajar \\
& & & \\
\hline $0-71$ & 16 & $46 \%$ & Belum Tuntas \\
$72-100$ & 19 & $54 \%$ & Sudah Tuntas \\
\hline Jumlah & 35 & $100 \%$ & \\
\hline
\end{tabular}

Sumber: Analisis Data Primer, 2019.

Setelah melakukan analisis dan refleksi hasil belajar siswa siklus I bahwa kentuntasan siswa secara klasikal belum mencapai target maka guru mata pelajaran bersama dengan peniliti mecoba melakukan perbaikan pada proses pembelajaran pada siklus selanjutnya. Pada siklus selanjutnya dalam hal ini siklus II ketuntasan belajar siswa diperoleh skor antara 0-71 berjumlah 7 dari 35 siswa dengan persentase $20 \%$ Sedangkan siswa yang memperoleh skor antara
72-100 berjumlah 28 dari 35 siswa dengan persentase ketuntasan $80 \%$. Hasil ini sudah lebih baik jika dibandingkan dengan skor perolehan siswa siklus I. Dengan demikian indikator ketuntasan belajar siswa telah tercapai dan itu artinya hasil penelitian ini berhasil karena secara klasikal kriteria ketuntasan yang di tetapkan sebagai indikator berhasilnya pembelajaran yaitu $80 \%$ sudah terpenuhi.

Tabel 4.Data Anlisis Ketuntasan Hasil Belajar Siswa Pada Siklus II

\begin{tabular}{cccc}
\hline Skor & Jumlah siswa & Persentase & Ketuntasan belajar \\
\hline $0-71$ & 7 & $20 \%$ & Belum Tuntas \\
$72-100$ & 28 & $80 \%$ & Sudah Tuntas \\
\hline Jumlah & 15 & $100 \%$ & \\
\hline
\end{tabular}

Sumber: Analisis Data Primer, 2019.

Peningkatan hasil belajar pada siklus II ini menunjukan pula bahwa telah ada peningkatan hasil belajar siswa dan guru telah mampu mengelola pembelajaran. Pada Siklus II target ketuntasan hasil belajar telah tercapai yaitu $80 \%$ siswa telah tuntas hasil belajarnya. Dengan peningkatan ini, penelitian ini telah berhasil mencapai target dan keberhasilan siswa dalam test siklus II memberi gambaran penerapan media pembelajaran powerpoint mampu meningkatkan hasil belajar siswa kelas X IPS 2 SMA Negeri 1 Baubau

\section{SIMPULAN DAN SARAN}

\section{Kesimpulan}

Berdasarkan hasil dalam penelitian ini dapat ditarik beberapa kesimpulan sebagai berikut : 1) Aktivitas belajar siswa dengan menggunakan media pembelajaran Powerpoin pada setiap siklus cenderung meningkat. Hal ini ditunjukan dengan skor rata-rata pada setiap siklusnya. Pada siklus I skor rata-rata aktivitas siswa adalah 2,5 dikategorikan cukup dan meningkat pada siklus II menjadi 3,1 yang berkategori baik. 2) Aktivitas mengajar guru dengan mennggunakan media pembelajaran Powerpoint pada setiap siklus cenderung meningkat. Hal ini ditunjukan dengan skor rata-rata pada setiap siklusnya. Pada siklus I skor rata-rata mengajar guru adalah 2,9 dikategorikan cukup dan meningkat pada siklus II menjadi 3,6 yang berkategori baik. 3)

Peningkatan hasil belajar geografi siswa Kelas X IPS2 SMA Negeri 1 Baubau meningkat dari ketuntasan belajar sebesar 26\%. Hal tesebut ditunjukan oleh ketuntasan pada siklus I sebejar 54\% dengan julam siswa tuntas hanya 19 orang dari 35 siswa meningkat menjadi $80 \%$ pada ketuntasan belajar siklus II dengan jumlah siswa yang tuntas menjadi 27 orang dari 35 orang siswa.

\section{Saran}

Adapun saran yang dapat peneliti sampaikan yaitu, antara lain: 1) Bagi sekolah, khususnya SMAN 1 Baubau dapat mencoba menerapkan model pembelajaran berbasis masalah ini dalam meningkatkan hasil belajar siswa serta dalam meningkatkan kualitaas belajar siswa selama proses pembelajaran. 2)

Bagi peneliti selanjutnya, teruslah 
belajar dan menggali informasi lebih jauh tentang model pembelajaran berbasis masalah untuk mempetajam kemampuan dalam menerapkan model ini pada kesempatankesempatan berikutnya agar memberikan hasil yang jauh lebih optimal. 3) Peneliti menyadari bahwa di dalam perencanaan penelitian, pelaksanaan penelitian dan peganalisaan data hasil penelitian sampai pada penarikan kesimpulan masih ada kekurangankekurangan baik dari segi penulisan termasuk penggunaan kata didalamnya. Hal itu karena peneliti hanyalah manusia biasa yang tidak sempurna dean tidak pernah luput dari kesalahan. Olehnya itu peneliti mengharapkan saran kritik yang bersifat konstruktif untuk kebaikan pada penulisan-penulisan berikutnya.

\section{DAFTAR RUJUKAN}

Daryanto.2010. Langkah-Langkah Media Pembelajaran. Jakarta

Komarun, Endang. 2014. Belajar dan pembelajaran interaktif. Bandung : Refika Adima

M. Zakiudin, Al-fauzi.2005. Pengaruh Penggunaan Media Autovisual Dalam Bentuk VCD terhadap motivasi dan prestasi sains biologi sub pokok bahasan "fotosintesis". Yogyakarta : Univertas Islam Negeri Sunan Kalijaga.

Sudjana.2002. Metode Statistika. Bandung : Tarsito

Susetyo, B. 2010. Statistika Untuk Analisis Data Penelitian. Bandung : Refika Ditama.

Suparno,p. 2008. Riset Tindakan untuk Pendidikan. Jakarta: PT.Gramedia Widiasarana

Sriyanto. 2009. Pemanfaatan Micrasoft Powerpoint Untuk Media Pembelajaran. Diambil dari HTTP://pamongsakaba.wordpress.com/ 2009/09/29/pemanfaatanmicrosoftpower-power-point-untukmedia-pembelajaran. pada tanggal 24 april 2018.
Syaefudin, Sa'ud. 2007. Pendidikan Dasar dan Menengah. Pekanbaru : Riau

Usman, Setiawati. 2001. Statistika. Bandung: Remaja Rosdakarya.

\section{Editor In Chief}

\section{Rosmini Maru}

rosminimaru@unm.ac.id

\section{Publisher}

Geography Education, Postgraduate Program, Universitas Negeri Makassar $\mathrm{Jl}$. Bonto Langkasa Gunungsari Baru Makassar, 90222 Kampus PPs UNM Makassar Gedung AB ruang 01, Indonesia

Email : ugj@unm.ac.id

Info Berlangganan Jurnal

085299874629 / Ihsan 